\title{
No Information Available
}

National Cancer Institute

\section{Source}

National Cancer Institute. No Information Available. NCI Thesaurus. Code C53269.

Information regarding the subject is unknown or inaccessible at this time. 